\title{
Biochemical responses, blood gas, oxidative stress and lipid peroxidation of goats transfused with fresh or stored whole homologous blood ${ }^{1}$
}

\author{
Nayanna B.S. Fonseca ${ }^{2 *}$, Jucélio S. Gameleira ${ }^{2}$, Jerson M. Cavalcante ${ }^{2}$, \\ Francisco L.C. Oliveira ${ }^{3}$, Clara S. Mori ${ }^{3}$, Rejane S. Sousa ${ }^{3}$, Antonio H.H. Minervino ${ }^{4}$ \\ and Raimundo A. Barrêto-Júnior ${ }^{2}$
}

\begin{abstract}
Fonseca N.B.S., Gameleira J.S., Cavalcante J.M., Oliveira F.L.C., Mori C.S., Sousa R.S., Minervino A.H.H. \& Barrêto-Júnior R.A. 2018. Biochemical responses, blood gas, oxidative stress and lipid peroxidation of goats transfused with fresh or stored whole homologous blood. Pesquisa Veterinária Brasileira 38(11):2070-2079. Laboratório de Medicina Interna Veterinária, Universidade Federal Rural do Semi-Árido, Av. Francisco Mota 572, Costa e Silva, Mossoró, RN 59625-900, Brazil. E-mail: nayanna_brunna@yahoo.com.br

Blood transfusion is a therapeutic procedure of great importance for veterinary medicine, in spite of only few studies in the literature on hemotherapy in goats. We aimed to evaluate the biochemical, blood gas, oxidative stress and lipid peroxidation of goats submitted to homologous transfusion of fresh whole blood or stored for 15 and 35 days. Eighteen adult male goats were submitted to a single phlebotomy to remove $30 \%$ of the blood volume, and we transfused $20 \mathrm{~mL} / \mathrm{kg}$ of whole blood stored in CPDA- 1 bags according to the experimental group, being: G0 composed goats who received fresh blood, G15 and G35 goats that received blood stored for 15 and 35 days, respectively. For the biochemical evaluation, blood gas, oxidative stress and lipid peroxidation, blood samples were collected at the following moments: before the induction of anemia (TC0); 6 hours after phlebotomy and before transfusion (TC1); 1, 6, 12, 24 and 96 hours after transfusion (T1, T6, T12, T24 and T96 respectively); 8,16 and 32 days after transfusion (T8d, T16d and T32d respectively). Before transfusion, blood samples were also withdrawn from the bags for the same analyzes. Statistical analyzes were performed in the statistical program GRAPHPAD PRISM 5.0, adopting a significance level of $5 \%$. The bags of blood stored for 15 and 35 days showed more biochemical changes, blood gas, oxidative stress and lipid peroxidation than fresh blood bags. As for the biochemical analysis, after the transfusion was observed an increase of the total protein, albumin, glucose and creatine kinase in the 3 groups, and elevation of total bilirubin, direct bilirubin, and urea in G15 and G35. The changes observed in the blood gas analysis had no clinical significance, as they were within the reference values for the species. The goats that received stored blood showed disorder in their antioxidant system through alteration of the SOD activity. In the analysis of lipid peroxidation no difference between the groups for the concentration of malondialdehyde was found. Thus, it can be concluded that transfusion of whole fresh stored blood in goats did not compromise the blood gases, lipid peroxidation and liver and renal functions of the transfused animals. In addition, the method was proved to be efficient to restore, among other components, the total protein and albumin. The transfusion, as performed in this study, proved to be safe for used in the clinical practice of goats.
\end{abstract}

INDEX TERMS: Blood gas stress, oxidative stress, lipid peroxidation, goats, hemotherapy, blood transfusion, biochemistry, hemogasometry, clinics.

\footnotetext{
${ }^{1}$ Received on March 1, 2018.

Accepted for publication on May 2, 2018.

${ }^{2}$ Laboratório de Medicina Interna Veterinária (LABMIV), Universidade Federal Rural do Semi-Árido (UFERSA), Av. Francisco Mota 572, Costa e Silva, Mossoró, RN 59625-900, Brazil. *Corresponding author: nayanna_brunna@yahoo.com.br
}

\footnotetext{
${ }^{3}$ Faculdade de Medicina Veterinária e Zootecnia (FMVZ), Universidade de São Paulo (USP), Avenida Prof. Dr. Orlando Marques de Paiva 87, Cidade Universitária, São Paulo, SP 05508 270, Brazil.

${ }^{4}$ Instituto de Biodiversidade e Floresta, Universidade Federal do Oeste do Pará (UFOPA), Rua Vera Paz, Unidade Tapajós, Salé, Santarém, PA 68035-110, Brazil.
} 
RESUMO.- [Respostas bioquímicas, hemogasométricas, estresse oxidativo e peroxidação lipídica de caprinos transfundidos com sangue homólogo total fresco ou armazenado.] A transfusão de sangue é um procedimento terapêutico de grande importância para medicina veterinária, apesar disto, na literatura há poucos estudos sobre hemoterapia em caprinos. Este trabalho teve como objetivo avaliar as respostas bioquímicas, hemogasométricas, estresse oxidativo e peroxidação lipídica de caprinos submetidos à transfusão homóloga de sangue total fresco ou armazenado por 15 e 35 dias. Foram utilizados 18 caprinos adultos, machos, submetidos a uma única flebotomia para retirada de $30 \%$ do volume sanguíneo e transfundidos com $20 \mathrm{~mL} / \mathrm{kg}$ de sangue total armazenado em bolsas CPDA-1 de acordo com o grupo experimental, sendo: o G0 composto por animais que receberam sangue fresco; G15 e G35 animais que receberam sangue armazenado por 15 e 35 dias, respectivamente. Para a avaliação bioquímica, hemogasométrica, estresse oxidativo e peroxidação lipídica foram coletadas amostras de sangue nos seguintes momentos: antes da indução da anemia (TC0); 6 horas após a flebotomia e antes de transfusão (TC1); $1,6,12,24$ e 96 horas após a transfusão (T1, T6, T12, T24 e T96, respectivamente); 8, 16 e 32 dias após a transfusão (T8d, T16d e T32d, respectivamente). Antes da transfusão, amostras de sangue também foram retiradas das bolsas para realização das mesmas análises. As análises estatísticas foram realizadas no programa estatístico GRAPHPAD PRISM 5.0, adotando-se nível de significância de 5\%. As bolsas de sangue armazenadas por 15 e 35 dias apresentaram mais alterações bioquímicas, hemogasométricas, estresse oxidativo e peroxidação lipídica do que as bolsas de sangue fresco. Quanto à análise bioquímica, após a transfusão observou-se aumento da proteína total, albumina, glicose e creatina quinase nos 3 grupos; e elevação da bilirrubina total, bilirrubina direta e ureia no G15 e G35. As alterações observadas na análise hemogasométrica não tiveram significado clínico, pois estavam dentro dos valores de referência para a espécie. Os animais que receberam sangue armazenado apresentaram desordem no seu sistema antioxidante demonstrada pela alteração da atividade da SOD. Na análise da peroxidação lipídica não houve diferença entre os grupos para a concentração de malondialdeído. Sendo assim, pode-se concluir que a transfusão de sangue homólogo total fresco ou armazenado em caprinos não comprometeu a gasometria, peroxidação lipídica e funções hepática e renal dos animais transfundidos. Além disso, mostrou-se eficiente em repor entre outros componentes, a proteína total e albumina. Desta forma, a transfusão, conforme realizada neste estudo, mostrou-se segura para ser utilizada na prática clínica desta espécie.

TERMOS DE INDEXAÇÃO: Estresse hemogasométricas, estresse oxidativo, peroxidação lipídica, caprinos, hemoterapia, transfusão de sangue, bioquímica, hemogasometria, clínica.

\section{INTRODUCTION}

Blood transfusion is an old therapeutic practice that throughout the years has been increasingly used, mainly due to important technological discoveries, such as the use of anticoagulants during the collection and analysis of differences among individuals to choose the donor (Lacerda 2005). In veterinary medicine, hemotherapy is widely used, and so it can be successful it is necessary to take care of the donor's choice, search standards for collection, blood bags processing and storage, as the establishment of parameters of quality control that indicates the blood's viability to be utilized (Lacerda 2005). In human medicine, there are many studies about standardization of quality control indicative parameters, in order to avoid storing lesions (Tomczak et al. 2010), however, in veterinary, these criteria are not well established yet. Studies on different animal species have demonstrated that the storing time can cause alteration in hematological, biochemical, blood gas, lipid peroxidation and antioxidants enzymes variables (Costa Júnior et al. 2008, Niinistö et al. 2008, Barros 2011, Bertoletti 2011, Sousa et al. 2012a, 2013, Tavares 2013). After transfusion, some of these alterations can be reflected in the animals' responses to the transfusion as observed by Sousa (2012) and Sousa et al. (2012b) while analyzing homologous and autologous blood transfusion in ovine, respectively. The blood bags used in veterinary medicine are the same used in human, being that in goat it is preferable the use of the CPDA- 1 bags (Tavares 2013).

Total blood transfusion is still the most used in veterinary medicine (Lacerda 2005), and its indication or-one of its components when it is necessary the reestablishment of the oxygen transport capacity by the blood, disorders in the hemostasis, in passive immunity transfer, in hypoproteinemia or hypovolemia (Reichmann \& Dearo 2001). In goat, the transfusion necessity occurs ordinarily justified by the anemia due to the presence of endo and ectoparasites or nutritional deficiencies. However, other causes as traumas and chirurgical interventions are observed in the veterinary medical care routine (Pugh 2004).

Although blood transfusion is a common practice in the small ruminant clinic, it is empirical because little information is available on the actual benefits or disorders generated by this therapeutic measure in goat. When it is considered the realization of this procedure using stored blood, these data are not found in literature, being necessary to study and evaluate the viability of the practice in this species. Thus, the present study aimed to evaluate the biochemical, blood gas, oxidative stress and lipid peroxidation responses of goat submitted to homologous blood transfusion of fresh or stored blood for 15 and 35 days.

\section{MATERIALS AND METHODS}

Study location. The study was performed in the Laboratório de Medicina Interna Veterinária (LABMIV) of the Universidade Federal do Semi-Árido (UFERSA), in Mossoró-RN, whose geographic coordinates are $5^{\circ} 11^{\prime \prime}$ of south latitude and $37^{\circ} 20^{\prime \prime}$ of west longitude. This study respected the ethical standards and animal care, being approved by the Ethics Committee on Animals Use (CEUA, Comisão de Ética no Uso de Animais) of this institution, under process number 23091.005234/2013-08 (Proposition 28/2013).

Animals. 18 adult male goat, of undefined breed and average weight of $21.75 \pm 3.48 \mathrm{~kg}$ were used after considered healthy through physical exam, hemogram, and feces parasitological exam, accordingly to the normal parameters for the species. They were maintained in collective stalls and underwent an adaptation period of 30 days. During this period, they received an application of endectocide based on ivermectin (Ivermectan ${ }^{\circledR}$, UCBVET, São Paulo, SP, Brazil), anthelminthic (Biozen ${ }^{\circledR}$, Biofarm, São Paulo, SP, Brazil) and doses of coccidiostat (Trissulfin ${ }^{\circledR}$, Ouro Fino, SP, Brazil). After this period, blood samples were collected for hemogram realization. The animals with 
normal globular volume were used in this study. None of the animals had previously been submitted to any kind of blood transfusion.

The animals' diet was composed by $75 \%$ of dry matter (hay of Canarana grass and Elephant grass) and 25\% of concentrated matter using commercial food (Rações Agromix ${ }^{\circledR}$, Maracanaú, CE, Brazil). The goat also received mineral and vitaminic supplementation every day (Caprinofós ${ }^{\circledR}$, Tortuga Companhia Zootécnica Agrária, Mairinque, SP, Brazil) (15g/animal) and they had free access to water.

Aiming to reduce the costs and to maximize the experimental logistic, all eighteen animals used for blood transfusion also served as donors, thus, in the moment of anemia induction, the blood was collected in bags avoiding waste of this important corporeal component. Six other animals were used in the experiment only as donors, whose have passed through the same adaptation, examination and feeding process.

Gathering and storage of the blood. Initially, the trichotomy and the asepsis of the jugular region were performed for the blood collection. Posteriorly, the animal was positioned in lateral decubitus for the jugular venous punction, and the needle placed in the caudocranial direction. The blood was stored in sterile plastic bags of the CPDA- 1 type (Line CompoFlex ${ }^{\circledR}$, Fresenius Kabi, Barueri, SP, Brazil), containing anticoagulant solution composed by citrate, phosphate, dextrose and adenine (CPDA-1). The bags were maintained under refrigeration at a temperature between $2^{\circ} \mathrm{C}$ and $6^{\circ} \mathrm{C}$, during 15 and 35 days, depending on the group. During the storage period, the bags were homogenized daily through the blood bag homogenizer (BHB_800, Benfer, São Paulo/SP, Brazil), so all the blood would be mixed with all the preservative solution.

Anemia induction and blood transfusion. Acute anemia was induced in all 18 goats by the removal of $30 \%$ of their blood volume, measured according to the calculation of the total blood volume of the animals, which according to Liebich et al. (2016) corresponds to 8\% of its corporal weight. The $30 \%$ percentage to induce acute anemia was based on previous studies with acute loss of blood in goat, but not yet published. Six hours after anemia induction, the total blood collected in CPDA-1 bags was transferred to the animals according to the experimental group: G0 (control group) received fresh blood transfusion (blood maintained in environment temperature for up to 6 hours after collection); G15 (15 days group) received transfusion of blood stored during 15 days; and G35 (35 days group) received transfusion of blood stored for 35 days. Each experimental group was composed by 6 animals presenting similar body weight.

Before the transfusion, the bags were removed from the fridge and left at environment temperature for about 30 minutes. In this moment, blood samples were taken from the bags to perform the microbiological, biochemical, blood gas, oxidative stress and lipid peroxidation analysis. For the hemoculture, the Pediatric Three-Phase Hemobac System (Probac ${ }^{\circledR}$, São Paulo/SP, Brazil) composed by a two faced laminoculture containing chocolate agar, Sabouraud agar and MacConkey agar was used. After, the bag was connected to transfusion equipment (Sangodrop ${ }^{\circledR}$ B LLM, Fresenius Kabi, Barueri, SP, Brazil) and this to a catheter for blood administration, the blood was transfused into the jugular vein. Each animal received $20 \mathrm{~mL}$ of total blood per kg of body weight during transfusion, volume considered safe to be administered (Hunt \& Moore 1990).

In the first 15 minutes of transfusion, the blood was transfused more slowly $(0.1 \mathrm{~mL}$ of blood $/ \mathrm{kg})$ for verification of possible adverse reactions, posteriorly, the velocity was elevated to $20 \mathrm{~mL}$ of blood per kilogram of body weight per hour (Reichmann \& Dearo 2001). In order to minimize the animals' stress, the transfusion was performed in a climatized environment with ambiance temperature varying from $22^{\circ} \mathrm{C}$ to $28^{\circ} \mathrm{C}$.

The biochemical parameters, oxidative stress and lipid peroxidation were evaluated from analysis of the blood samples collected in the following moments: before anemia induction (TC0); 6 hours after anemia induction and before the transfusion (TC1); 1, 6, 12, 24 and 96 hours after transfusion (T1, T6, T12, T24 and T96, respectively); 8, 16 and 32 days after the transfusion (T8d, T16d and T32d, respectively). The blood gas parameters were evaluated from TC0 to T96.

Biochemical analysis. For the biochemical analysis, 2 total blood samples were collected into tubes of $8.5 \mathrm{~mL}$ without anticoagulant, which were centrifuged at $1,500 \mathrm{~g}$ for 15 minutes to obtain the serum. One of these tubes was covered with aluminum paper to protect the serum from the contact with the ambience light, and it was used for determination of the bilirubin concentration. Besides, the total blood samples were collected in tubes with sodium fluoride for determination of the glucose and lactate concentrations.

The biochemical evaluation was performed from the determination of the total protein concentration (TP), albumin, urea, creatinine, total bilirubin (TB), direct bilirubin (DB), and activity of lactate dehydrogenase enzymes (LDH), aspartate aminotransferase (AST), gamma-glutamyl transferase (GGT), and creatine kinase (CK) in serum samples. The glucose and lactate concentration were determined in plasma samples. The biochemical parameters were determined in an automatic biochemical analyzer (RX Daytona, Randox ${ }^{\circledR}$, Antrim, UK) using commercial kits of the same brand, except for the concentrations of the sodium and potassium electrolytes, which were determined in serum, using a flame photometer (FC-130, Celm, São Paulo/SP, Brazil); and the indirect bilirubin concentration (IB), that was obtained by calculating the difference between TB and DB.

Blood gas analysis. The blood gas analysis was based in the analysis of the potential of hydrogen ion $(\mathrm{pH})$, partial oxygen pressure $\left(\mathrm{PO}_{2}\right)$, partial carbon dioxide $\left(\mathrm{PCO}_{2}\right)$, oxygen saturation $\left(\mathrm{SO}_{2}\right)$, bicarbonate $\left(\mathrm{HCO}_{3}^{-}\right)$, base excess $(\mathrm{BE})$, and total concentration of carbon dioxide $\left(\mathrm{TCO}_{2}\right.$ ). For this evaluation, total venous blood samples were used, collected in heparinized syringes and analyzed in portable hemogasometer (i-STAT ${ }^{\circledR} 1$, Abbott Point of Care Inc, Illinois, USA), using (i-STAT ${ }^{\circledR}$ CG8+ (Abbott Laboratories, Illinois, USA) cartridges. Each determination was corrected according to the rectal temperature of the animal.

Oxidative stress and lipid peroxidation analysis. The oxidative stress was evaluated from the activity of the superoxide dismutase (SOD) and the glutathione peroxidase (GPX). The total blood samples for determination of the SOD and GPX were collected in vacuo in two tubes of $8.5 \mathrm{~mL}$ containing lytic heparin as anticoagulant. After, they were centrifuged at $1,050 \mathrm{~g}$ for 10 minutes for the removal of plasma and buffycoat. Then, the red blood cells were washed three times with saline solution $(\mathrm{NaCl} 0,9 \%)$ and the pap of red blood cells obtained was conditioned in amber microtubes and frozen in a freezer at $-80^{\circ} \mathrm{C}$ for posterior analysis of SOD and GPX. The SOD and GPX concentrations were determined in an automatic biochemical analyzer (RX Daytona, Randox ${ }^{\circledR}$, Antrim, UK) using the commercial kits (Ransod e Ransel - Randox ${ }^{\circledR}$, Antrim, UK).

The lipid peroxidation was evaluated through the determination of the malondialdehyde (MDA) in serum samples using the method described by Esterbauer \& Cheeseman (1990).

Statistical analysis. The statistical analysis was processed with help from the statistical program GRAPHPAD PRISM 5.0. The significance level adopted was of $5 \%$. To verify the distribution of data in the diverse variable studied, these were submitted to the Kolmogorov Smirvov test. The statistical analysis for comparison 
among the bags from the three groups was performed through analysis of variance followed by the Tukey test for comparison of averages. The evaluation of the animals in different moments was performed through analysis of variance of two ways with repeated measures in time (two-way repeated measure ANOVA), followed by the comparison test of averages of Tukey for comparison between the groups in different moments; and Bonferroni for comparison between the TC 0 and the TC1 and of the subsequent times.

\section{RESULTS}

\section{Bags analysis}

In the biochemical analysis of the bags, no difference was observed among the B0, B15 and the B35 bags as for total protein, albumin and sodium concentrations. However, the bags differed as for the potassium, glucose, lactate and LDH concentrations, in which the bags with stored blood (B15 and B35) presented higher concentration of potassium $(\mathrm{P}<0,0001)$ and $\mathrm{LDH}$ when compared to the fresh blood bags. Besides that, it was observed higher lactate concentration $(\mathrm{P}<0,05)$ in the blood stored for 35 days e lower glucose content $(\mathrm{P}<0,05)$ in the blood stored for 15 days (Table 1 ).

No statistical difference was observed among the bags B0, $\mathrm{B} 15$ and $\mathrm{B} 35$ for $\mathrm{TCO}_{2}, \mathrm{HCO}_{3}^{-}$and BE. However, the bags differed as for $\mathrm{pH}, \mathrm{pO}_{2}, \mathrm{pCO}_{2}$ and $\mathrm{SO}_{2}$, in which the blood stored for 15 and 35 days presented lower values of $\mathrm{pH}(\mathrm{P}<0.05)$ than the fresh blood; the blood stored for 15 days presented higher $\mathrm{pCO}_{2}(\mathrm{P}<0.01)$; and the blood stored for 35 days presented higher $\mathrm{pO}_{2}$ e $\mathrm{SO}_{2}(\mathrm{P}<0.0001)$ than the fresh blood and the blood stored for 15 days (Table 1 ).

The bags oxidative stress evaluation showed that the activity of the SOD was lower $(\mathrm{P}<0.01)$ in the blood stored for 35 days, while it was not observed difference in the GPX activity for the stored or fresh blood (Table 1).
The bags lipid peroxidation evaluation showed higher MDA concentrations $(\mathrm{P}<0.01)$ in the blood stored for 35 days when compared to the fresh blood or to the blood stored for 15 days (Table 1 ).

In the microbiological analysis of the bags, all samples cultures performed during the experimental period were negative for any bacterial growth.

\section{Biochemical analysis}

No difference was observed between groups for total protein concentration, indirect bilirubin, glucose, lactate, potassium, and for the LDH, AST, GGT and CK enzymes.

The total protein reduced $(\mathrm{P}<0.0001)$ after anemia induction in TC1 in all groups. After transfusion, there was a TP increase $(\mathrm{P}<0.0001)$ from $\mathrm{T} 1$ in the $\mathrm{G} 0$ and from T6 in the G35 (Table 2).

In relation to the albumin concentration, there was difference among the groups $(\mathrm{P}<0.01)$, in which G0 present higher content of albumin than the animals from the G15 from the moments T6 to T96; and higher than the G15 and the G35 in T16d. In the time comparison, after anemia induction there was reduction $(\mathrm{P}<0.0001)$ of the concentration of serum albumin in the TC1 in all groups. After transfusion, in the evaluation within each group, it was observed a significative increase $(\mathrm{P}<0.0001)$ of the albumin in T1 and T16d of the G0 and T32d of the G15; and a numeric increase in T1 of the G15 and G35 (Table 2).

The concentration of total bilirubin was higher $(\mathrm{P}<0.05)$ from TC0 to T96 in the G15 and G35. Between times, after anemia induction, the concentration of total bilirubin reduced $(\mathrm{P}<0.0001)$ in the TC1 and from T24 to T32d of the G15, and from TC1 to T32d of the G35. Nevertheless, this reduction

Table 1. Mean values (X) and standard deviations (S) of biochemical, blood gas variables, lipid peroxidation and oxidative stress of fresh whole blood (B0) stored in CPDA-1 bags for 15 days (B15) or stored for 35 days

\begin{tabular}{|c|c|c|c|c|}
\hline \multirow{2}{*}{\multicolumn{2}{|c|}{ Variables }} & \multicolumn{3}{|c|}{ Blood bags (CPDA-1) } \\
\hline & & \multirow{2}{*}{$\frac{\mathrm{B} 0(\mathrm{X} \pm \mathrm{S})}{159.00 \pm 3.03}$} & \multirow{2}{*}{$\frac{\mathrm{B} 15(\mathrm{X} \pm \mathrm{S})}{155.00 \pm 8.07}$} & \multirow{2}{*}{$\frac{\text { B35 }(\mathrm{X} \pm \mathrm{S})}{148.00 \pm 15.85}$} \\
\hline Biochemistry & Sodium (mmol/L) & & & \\
\hline & Potassium (mmol/L) & $3.25 \pm 0.30^{\mathrm{B}}$ & $8.05 \pm 1.76^{\mathrm{A}}$ & $8.78 \pm 1.41^{\mathrm{A}}$ \\
\hline & Glucose (mmol/L) & $31.43 \pm 3.21^{\mathrm{A}}$ & $27.63 \pm 2.68^{\mathrm{B}}$ & $27.90 \pm 1.08^{\mathrm{AB}}$ \\
\hline & Lactate $(\mathrm{mmol} / \mathrm{L})$ & $3.01 \pm 0.54^{\mathrm{B}}$ & $5.04 \pm 1.16^{\mathrm{B}}$ & $8.40 \pm 3.64^{\mathrm{A}}$ \\
\hline & LDH (U/L) & $246.27 \pm 60.46^{\mathrm{C}}$ & $441.33 \pm 65.54^{\mathrm{A}}$ & $355.58 \pm 40.61^{\text {В }}$ \\
\hline & Total protein (g/L) & $55.08 \pm 4.25$ & $55.70 \pm 1.98$ & $57.63 \pm 3.75$ \\
\hline & Albumin (g/L) & $27.33 \pm 1.51$ & $27.00 \pm 1.67$ & $26.50 \pm 2.66$ \\
\hline \multirow[t]{7}{*}{ Blood gas } & $\mathrm{pH}$ & $7.01 \pm 0.08^{\mathrm{A}}$ & $6.89 \pm 0.06^{\mathrm{B}}$ & $6.88 \pm 0.08^{\mathrm{B}}$ \\
\hline & $\mathrm{pCO}_{2}(\mathrm{mmHg})$ & $78.78 \pm 6.41^{\mathrm{B}}$ & $93.13 \pm 5.85^{\mathrm{A}}$ & $85.02 \pm 8.22^{\mathrm{B}}$ \\
\hline & $\mathrm{pO}_{2}(\mathrm{mmHg})$ & $42.67 \pm 4.55^{\mathrm{B}}$ & $44.50 \pm 4.64^{\mathrm{B}}$ & $121.17 \pm 40.54^{\mathrm{A}}$ \\
\hline & $\mathrm{SO}_{2}(\%)$ & $53.00 \pm 8.15^{\mathrm{B}}$ & $47.00 \pm 6.03^{\mathrm{B}}$ & $90.50 \pm 7.31^{\mathrm{A}}$ \\
\hline & $\mathrm{TCO}_{2}(\mathrm{mmol} / \mathrm{L})$ & $22.67 \pm 3.33$ & $21.33 \pm 1.97$ & $18.67 \pm 3.61$ \\
\hline & $\mathrm{HCO}_{3}^{-}(\mathrm{mmol} / \mathrm{L})$ & $20.35 \pm 3.74$ & $18.35 \pm 1.95$ & $16.13 \pm 3.43$ \\
\hline & $\mathrm{BE}(\mathrm{mmol} / \mathrm{L})$ & $-10.83 \pm 4.36$ & $-14.67 \pm 2.88$ & $-17.17 \pm 4.83$ \\
\hline \multirow[t]{2}{*}{ Oxidative stress } & SOD (U/g Hb) & $3331.48 \pm 466.30^{A}$ & $4350.23 \pm 957.11^{\mathrm{A}}$ & $1948.14 \pm 777.62^{\text {B }}$ \\
\hline & GPx (U/g Hb) & $540.93 \pm 202.42$ & $519.22 \pm 104.71$ & $359.63 \pm 108.04$ \\
\hline Lipid peroxidation & $\operatorname{MDA}(\mu \mathrm{mol} / \mathrm{L})$ & $0.83 \pm 0.19^{\mathrm{B}}$ & $1.06 \pm 0.28^{\mathrm{B}}$ & $1.48 \pm 0.35^{\mathrm{A}}$ \\
\hline
\end{tabular}

$\overline{\mathrm{LDH}}=$ Lactate dehydrogenase enzymes, $\mathrm{BE}=$ base excess, $\mathrm{SOD}=$ superoxide dismutase, $\mathrm{GPx}=$ glutathione peroxidase, $\mathrm{MDA}=$ malondialdehyde; ${ }^{\mathrm{A}} \mathrm{B}, \mathrm{C}$ Statistical difference $(\mathrm{p}<0.05)$ between groups at the same time. 


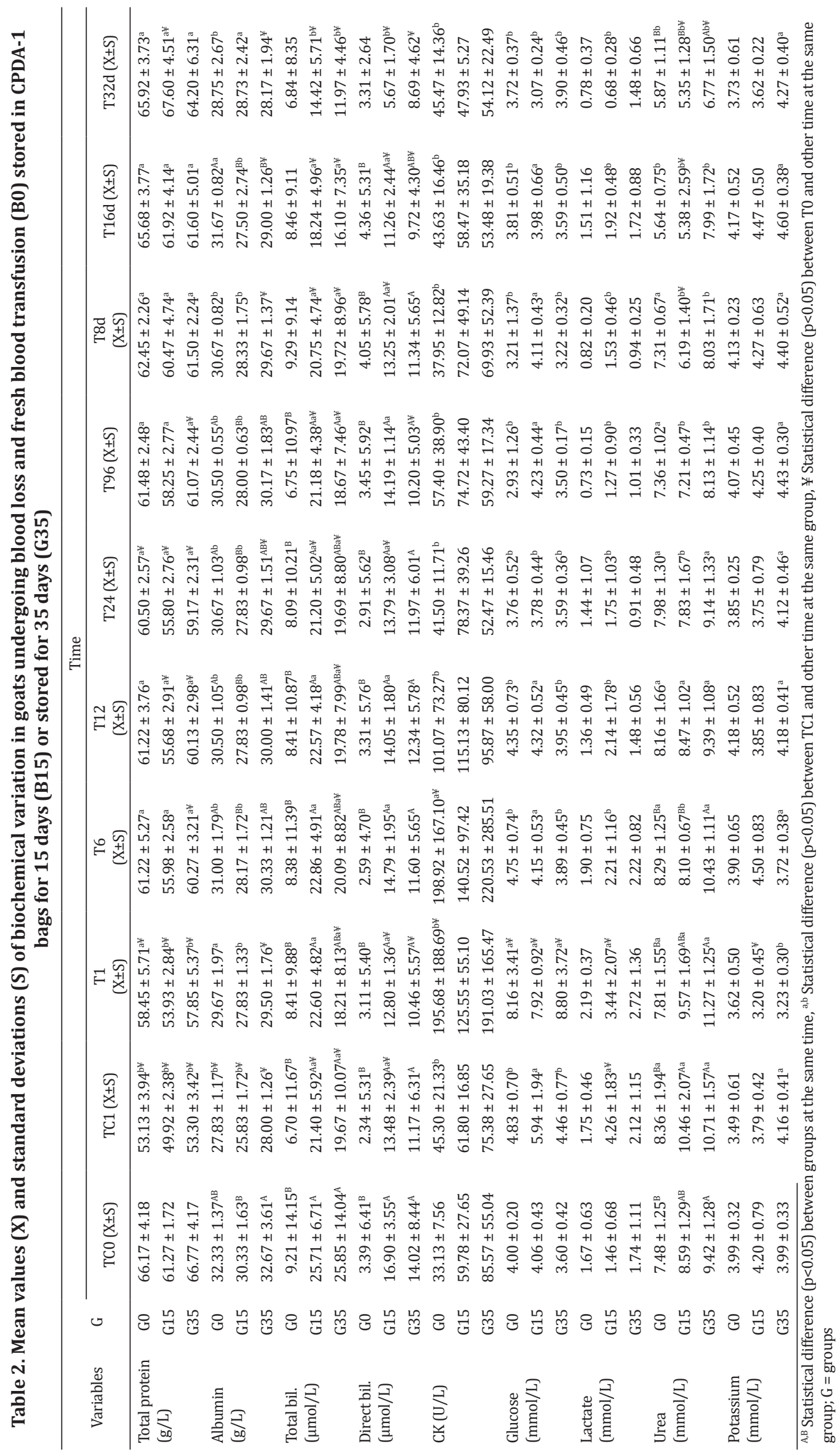


after transfusion was observed only in the T32d of these groups (Table 2).

The concentration of direct bilirubin was higher $(\mathrm{P}<0.01)$ from TC0 to T16d in the G 15 and G35 groups. Between times, after anemia induction, the concentration of direct bilirubin reduced $(\mathrm{P}<0.0001)$ in the TC1, T1, T24, T8d, T16d and T32d of the G15 and in T1, T96, T16d and T32d of the G35. After the transfusion, the reduction was observed only in T32d of the G15 (Table 2).

The concentration of indirect bilirubin after anemia induction reduced $(\mathrm{P}<0.0001)$ in $\mathrm{T} 1, \mathrm{~T} 12, \mathrm{~T} 24, \mathrm{~T} 16 \mathrm{~d}$ and T32d of the G35, while after transfusion, this reduction was observed only in T32d of the G35 (data not shown).

As for the analyzed enzymes in the time evaluation after the anemia induction, there was an increase $(\mathrm{P}<0.0001)$ of the CKactivity in the $\mathrm{T} 1$ and $\mathrm{T} 6$ of the $\mathrm{G} 0$ (Table 2 ) and reduction $(\mathrm{P}<0.0001)$ of the LDH activity in T32d of the G0 and the G15; and of the GGT in TC1 and T1 of the G35 (data not shown). After transfusion there was an increase $(\mathrm{P}<0.0001)$ of the LDH activity in T6, T12 and T8d of the G0, in T1, T6 and T12 of the G35; of the AST in T6 and T12 of the G0, in T1, T6 and T12 of the G15 and the G35; of the GGT in T8d, T16d and T32d in the G0, in T6 and T32d in the G35 (data not shown); significative of the CK in T6 of the G0 and numeric in the G15 and G35 from T1 (Table 2).

The glucose concentration after the anemia induction increased $(\mathrm{P}<0.0001)$ in $\mathrm{T} 1$ in all groups. After transfusion, an increase $(\mathrm{P}<0.0001)$ of the glucose in $\mathrm{T} 1$ of the $\mathrm{G} 0$ and G35 was observed, while in the G15 there was a reduction $(\mathrm{P}<0.0001)$ in T24 and T32d (Table 2).

The lactate concentration after anemia induction increased $(\mathrm{P}<0.0001)$ in TC1 and T1 of the G15, however, after transfusion, a reduction $(\mathrm{P}<0.0001)$ in the lactate from
T6 to T32d of the G15 was observed. The higher glucose and lactate values post-transfusion were observed in the T1 of the three groups (Table 2).

In relation to the urea concentration, there was a difference $(\mathrm{P}<0.01)$ between the groups, in which in TC1 of the G15 and G35 and in T1, T6 and T32d of the G35 there was a higher urea concentration than the $\mathrm{GO}$. In time comparison after anemia induction, there was a reduction of the urea from the T8d of the G15 and T32d of the G35. After transfusion a reduction $(\mathrm{P}<0.0001)$ of the urea from $\mathrm{T} 16 \mathrm{~d}$ of the G0; in-T6 and from T24 in the G15; and from T96 in the G35 was observed (Table 2).

In relation to the creatinine concentration, there was a difference $(\mathrm{P}<0.05)$ among the groups, in which from T96 to T16d, the G0 presented the highest creatinine values. In comparison among time, after the transfusion there was an increase $(\mathrm{P}<0.0001)$ of the creatinine only in $\mathrm{T} 32 \mathrm{~d}$ of the G35 (data not shown).

The sodium concentration did not differ among the groups, neither among the times studied (data not shown).

The potassium concentration reduced $(\mathrm{P}<0.0001)$ after anemia induction in T1 of the G15 and after transfusion in T1 of the G35 (Table 2).

\section{Blood gas analysis}

There was no difference among the groups and times studied for $\mathrm{BE}, \mathrm{HCO}_{3}{ }^{-}$and $\mathrm{TCO}_{2}$ (data not shown).

In relation to the blood $\mathrm{pH}$, there was difference among the groups in TC1 and T96 moments, in which the G15 showed lower $\mathrm{pH}$. In time comparison, an increase $(\mathrm{P}<0.01)$ in the pH in T1 of the G15 was observed when compared to the TC0 (Fig.1).
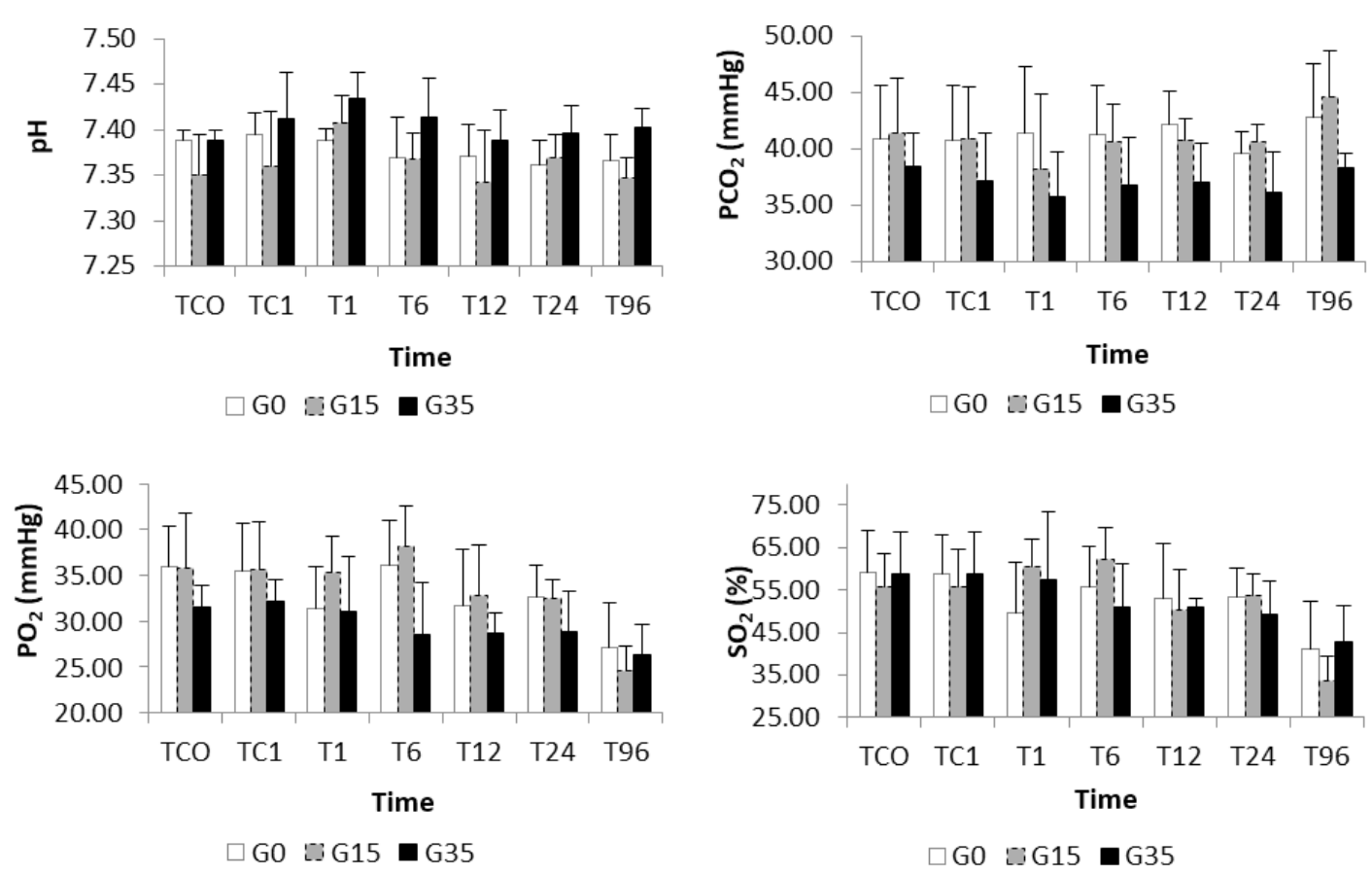

Fig.1. Blood gas analysis of goat submitted to blood loss, and posteriorly to the total homologue fresh blood transfusion (G0), stored in CPDA-1 bags for 15 days (G15) or 35 days (G35), in the analyzed times. 

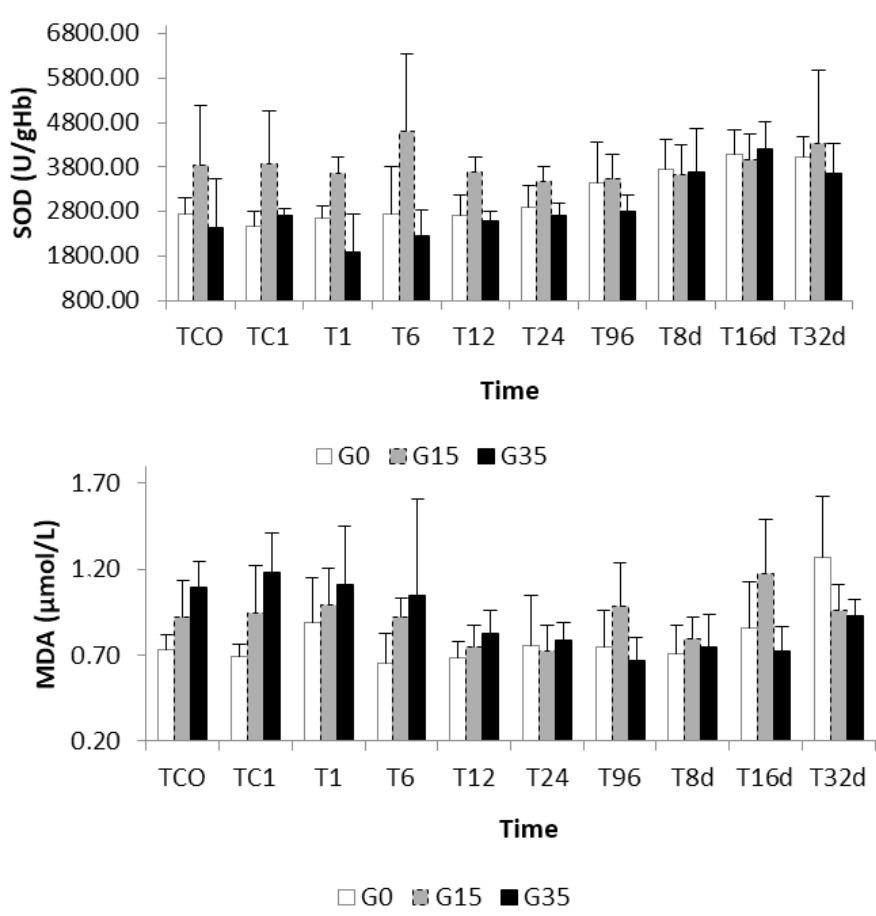

Fig.2. SOD activity and MDA concentration of goat submitted to blood loss, and posteriorly to the total homologue fresh blood transfusion (G0), stored in CPDA-1 bags for 15 days (G15) or 35 days (G35), in the analyzed times.

As for the $\mathrm{PCO}_{2}$, the $\mathrm{G} 0$ presented higher values $(\mathrm{P}<0.05)$ in $\mathrm{T} 1$ and the $\mathrm{G} 15$ presented higher $(\mathrm{P}<0.05) \mathrm{PCO}_{2}$ in T96 (Fig.1).

The $\mathrm{PO}_{2}$ was higher $(\mathrm{P}<0.05)$ in $\mathrm{T} 6$ of the $\mathrm{G} 0$ and $\mathrm{G} 15$.In time comparison after anemia induction and blood transfusion, a reduction $(\mathrm{P}<0.0001)$ in the $\mathrm{PO}_{2}$ and $\mathrm{SO}_{2}$ in $\mathrm{T} 96$ of the $\mathrm{G0}$ and G15 was observed (Fig.1).

\section{Oxidative stress and lipid peroxidation analysis}

The SOD activity was higher $(\mathrm{P}<0.01)$ in the basal moment, Tc1, T1, T6 and T12 of the G15; whereas lower activity $(\mathrm{P}<0.01)$ was observed in the G35. In time comparison after anemia induction, an increase $(\mathrm{P}<0.0001)$ of the SOD in T16d of the G0 and G35 was observed, and after the transfusion in T16d and T32d of the G0 e in T16d of the G35 (Fig.2).

The GPX activity did not differ among the groups and times studied (data not shown).

The MDA concentrations did not differ among groups in none of the analyzed moments. However, in time comparison after anemia induction and blood transfusion, an increase $(\mathrm{P}<0.0001)$ of the MDA in T32d of the G0 was observed; and a reduction $(\mathrm{P}<0.0001)$ of the MDA of the G35 after anemia induction in T96 and after transfusion in T96, T8d and T16d (Fig.2).

\section{DISCUSSION}

In the bags' biochemical analysis, no difference was observed in the potassium and total protein concentration among the three periods of storage of the blood bags, corroborating with
Tavares (2013) that, when analyzing the goat blood stored in CPDA-1 bags, also did not observed alteration in these parameters until the storage period of 35 days.

The bags stored for 15 and 35 days presented higher potassium values than the bags of fresh blood. This potassium elevation in the stored blood has already been found in other studies (Wallas 1979, Niinistö et al. 2008, Sousa 2012, Sousa et al. 2013) and occurs because during the storage, the temperature reduces the activity of the ATPase in the erythrocyte membrane, preventing the active transportation of $\mathrm{Na}^{+} / \mathrm{K}^{+}$(sodium/potassium), with this there is the increase of intracellular sodium and reduction of intracellular potassium (Wallas 1979). According to Tomczak et al. (2010) the $\mathrm{K}^{+}$measurement in the extracellular environment is a useful marker for the quality control during the preservation.

The blood stored for 15 days presented lower glucose content when compared to the fresh blood. According to Hess \& Greenwalt (2002), this glucose reduction occurs because during storage the glucose is used by the erythrocytes as energetic source for production of ATP. Besides that, Tavares (2013), when evaluating the goat blood stored in CPDA-1 bags, did not observe glucose content alteration throughout the storage period of 35 days, and associated it to the low consume of the same by goat red blood cells. That explains why the blood stored for 35 days in this study did not differ in the glucose content in relation to the fresh blood.

The blood stored for 35 days presented higher lactate content than the fresh blood, and the blood stored for 15 days, corroborating with other studies (Niinistö et al. 2008, Sousa et al. 2013, Tavares 2013). According to Högman \& Meryman (1999) the lactate levels increase during the storage due to the glycolysis for the ATP production and it is associated to the $\mathrm{pH}$ changes, being that, for each molecule of metabolized glucose, two lactate molecules are produced. In this way, occurs the acidification of the mean, constituting one of the greatest problems in red blood cells preservation and limiting factor for its availability (Tomczak et al. 2010).

In the blood stored for 15 and 35 days, the LDH values were higher than the ones of the fresh blood. As this enzyme is present in high quantities in the red blood cells, studies with equine blood storage have used the activity of this enzyme to assist in the hemolysis evaluation (Mudge et al. 2004). Therefore, in the present study it is suggested that hemolysis has occurred in the stored blood.

In the blood gas analysis was not observed statistical difference among the bags for the $\mathrm{TCO}_{2}, \mathrm{HCO}_{3}^{-}$and $\mathrm{BE}$. These three indexes are calculated from other parameters that were measured through the blood sample reading in the cartridge that is inserted in the hemogasometer. The $\mathrm{HCO}_{3}{ }^{-}$is responsible for approximately $95 \%$ of the $\mathrm{TCO}_{2}$ measured (Carlson \& Bruss 2008), and this has not altered in this study, thence the $\mathrm{HCO}_{3}$ - also did not suffered alteration in its measurement. The $\mathrm{BE}$ is an indicator of the normal bicarbonate deviation (Carlson \& Bruss 2008), in this way, as in this study there was no alteration in the bicarbonate, consequently there was also no alteration in the BE. Tavares (2013) and Sousa et al. (2013) when evaluating the goat and ovine blood stored in CPDA-1 bags respectively, did not observed bicarbonate alteration until the storage period of 35 days, corroborating with this study. However, Tavares (2013) observed an elevation in the 
basis deficit starting in 21 days of storage, and reduction of the $\mathrm{TCO}_{2}$ starting on 35 days of storage.

The blood bags stored for 15 and 35 days presented lower $\mathrm{pH}$ values when compared to the fresh blood bags, corroborating with other studies (Niinistö et al. 2008, Sousa et al. 2013, Tavares 2013). According to Hess (2009), this lower pH value in the stored blood occurs because during storage, the glucose degradation leads to the metabolites production, as lactate and $\mathrm{H}^{+}$ions, with consequent reduction of the $\mathrm{pH}$ and acidity elevation. However, this acidity elevation in the stored blood bags was not enough to increase the $\mathrm{HCO}_{3}{ }_{3}^{-}$consumption and consequently initiate a reduction on its levels.

The blood bags stored for 15 days presented higher $\mathrm{PCO}_{2}$, corroborating with other studies (Sousa et al. 2013), in which the storage caused elevation of this gasometric variable. According to Sousa et al. (2012a), this $\mathrm{CO}_{2}$ pressure elevation during storage occurs mainly to neutralize the lactic acid resulting from the cellular metabolism that results in the $\mathrm{CO}_{2}$ synthesis.

The blood stored for 35 days presented higher $\mathrm{PO}_{2} \mathrm{e}$ $\mathrm{SO}_{2}$, corroborating with the goat blood conservation study performed by Tavares (2013). The $\mathrm{PO}_{2}$ increase can occur due to the oxygen passage from the external to the internal environment of the bag, since these are permeable (Högman \& Meryman 1999). According to the hemoglobin dissociation curve that represents the oxygen affinity by the red blood cell, as higher the oxygen partial pressure values, higher will be the oxygen saturation values (Harvey 2008), thus this elevation in the oxygen partial pressure justifies the oxygen saturation increase in the bags stored for 35 days.

In the oxidative stress evaluation, there was lower activity of the SOD enzyme in the bags stored for 35 days. According to Hatherill et al. (1991), in oxidizing conditions, the presence of enzymes as SOD provides protection of the red blood cells against hemolysis. Thus, it is suggested in this study that the lower activity of SOD in the 35-day bags is related to the longer storage time that the red blood cells were exposed to the free radicals, resulting in a higher consumption of the SOD enzyme and consequently reducing its antioxidative potential.

In the lipid peroxidation evaluation, it was observed bigger formation of MDA in the 35-day bags. This parameter determination is used to estimate the intensity of the lipid peroxidation, in which higher the oxidative lesion of the red blood cell membrane and subsequent hemolysis, higher will be the formation of the MDA (Jóźwik et al. 1997). Thus, it is suggested in this study that the red blood cells of the 35-day bags suffered hemolysis by oxidative damage caused by the longer storage period.

In this study was observed that after acute blood loss, there was a reduction in the total protein in all groups for values below normal for the goat species $(62-79 \mathrm{~g} / \mathrm{L}$ ) (Jackson \& Cockcroft 2002). However, after one hour of transfusion on the G0 and 6 hours of transfusion in the G15 and G35 was possible to observe the increase in this variable, and the return to the baseline values (TC0) occurred in the T6 of the G0 and G15 and T8d of the G35. Argôlo (2014) when analyzing the effects on acute blood loss in goat by the removal of $30 \%$ of the blood, also verified the reduction of the total protein, which returned to the baseline values on 24 days post challenge. Thus, it is evident that the fresh or stored blood transfusion restores the total protein, which maintained itself, unaltered during the storage period, and can be used in cases of hypoproteinemia.

After blood loss, there was albumin reduction in all groups for values under normal for the goat species $(29-43 \mathrm{~g} / \mathrm{L})$ (Jackson \& Cockcroft 2002). Argôlo (2014) when analyzing the effects of acute blood loss in goat by the removal of $30 \%$ of the blood, also verified albumin reduction, which returned to baseline values only 8 days post challenge. In this study, after 1 hour of transfusion in the G0 and G15 and 6 hours of transfusion in the G35, baseline values returned (TC0). In this way, it can be observed that after the transfusion there was an increase of the albumin in the T1 of the G0 (significative), of the G15 and G35 (numeric), suggesting that the total fresh and stored blood restores the albumin in cases of hypoalbuminemia.

The bilirubin is the main product of the metabolization of the hemoglobin, and its level increase in case of hemolysis (Tennant \& Center 2008). In this study, during comparison between groups, since the beginning was observed higher concentration of total bilirubin and direct bilirubin in the animals that received stored blood; the higher bilirubin concentration in these groups did not have clinical significance, because it did not exceed the reference values for the species of 1.71-29.24 $\mu \mathrm{mol} / \mathrm{L}$ (Pugh 2004). Thus, before the increase of the normal levels of bilirubin, it can be noticed that there was no hemolysis of the red blood cells transfused, and the fresh or stored blood transfusion did not cause hepatic lesion.

The AST, GGT, LDH and CK analysis was performed to verify possible post-transfusion hepatic and/or muscle lesions. The activity of these enzymes did not differ among groups. Nevertheless, between times was observed that after transfusion there was LDH and AST activity increase in the 3 groups studied; of the GGT in the G0 and G35 (data not shown); and the CK in the G0 (significative increase) and in the G15 and G35 (numeric increase) (Table 2). From these alterations observed, only CK rose above the reference values for the species of 0-100U/L (Jackson \& Cockcroft 2002) in the 3 groups, returning to the normal values after 24 hours of the transfusion. The probable hypothesis is that during the period that the animals remained in decubitus for the transfusion fulfillment, micro muscle lesions occurred elevating the content of this enzyme. This finding was reported by Sousa (2012) in ovine.

After the transfusion a significant increase of the glucose was observed in T1 of the G0 and G35 and numeric in T1 of the G15 above reference values for the species of $2.4-4.0 \mathrm{mmol} / \mathrm{L}$ (Jackson \& Cockcroft 2002); yet, 6 hours after the transfusion in the G35 and 24 hours in the G0 and G15, the values returned to normal. Thus, nutrients (e.g., dextrose) contained in the blood bags were converted after the transfusion into energy source (glucose), so that initially there was a serum glucose increase of the animals. Besides that, it can also be observed that the hepatic function of the animals was not committed through the transfusion, since the liver promptly balanced the serum glucose levels.

The lactate concentration after acute blood loss, increased in the G15, Argôlo (2014) when analyzing the effects of acute blood loss in goat by removal of $30 \%$ of blood volume, also verified this lactate transitional increase, which derives from the tissue hypoperfusion provoked by the acute blood loss. Still about the lactate, in spite the elevation of its levels in the blood bags stored for 35 days, after the transfusion it was 
not observed significant alterations in this group. Thus, it can be noticed that the hepatic function in animals was not committed through the transfusion, since the liver promptly balanced the serum lactate levels.

The urea concentration was higher after acute blood loss (TC1) in the G15 and G35, and after transfusion (T1, T6 and T32d) in the G35 than in the animals that received fresh blood. In these moments, there was a discreet elevation of the urea in relation to the reference values for the species of 4.0-8.6mmol/L (Jackson \& Cockcroft 2002), but that 6 hours after the transfusion in the G15 and 96 hours after transfusion in the G35, these values had already returned to the species normal. Thus, it can be observed that the transfusion improved the renal perfusion even in animals that received stored blood.

The creatinine, despite being higher in the G0 from T96 to T16d, maintained itself inside the reference values for the species of 54-123 $\mathrm{mol} / \mathrm{L}$ (Jackson \& Cockcroft 2002).

The storage time despite having affected the $\mathrm{Na}^{+} / \mathrm{K}^{+}$pump provoking greater efflux of potassium ions in the blood bags stored for 15 and 35 days, it was not observed post-transfusion relevant changes in the sodium and potassium levels of the transfused animals. It was observed only a light and transitory reduction of the potassium concentration in T1 of the G35, however in the $\mathrm{T} 6$, it had already returned to the reference values for the species of 3.4-6.1 mmol/L (Jackson \& Cockcroft 2002). Thus, in this study it became evident that the renal function of resorption of these electrolytes was occurring correctly, as for the activity of the $\mathrm{Na}^{+} / \mathrm{K}^{+}$pump, which balanced the potassium levels promptly after the transfusion.

In relation to the blood gas analysis of the goats, it was found that, like the bags, the animals did not differ regarding the $\mathrm{TCO}_{2}, \mathrm{HCO}_{3}^{-}$and $\mathrm{BE}$ parameters. In comparison between groups, it was found that the animals of the G15 presented lower $\mathrm{pH}$ and higher $\mathrm{PCO}_{2}$ in the T96, while in time comparison these animals presented lower $\mathrm{PO}_{2}$ and $\mathrm{SO}_{2}$ also in T96, as compensatory mechanism. These alterations are characteristics of respiratory acidosis, which develop due to the difficulty of oxygen transportation. In an attempt to correct this imbalance ( $\mathrm{pH}$ reduction and $\mathrm{PCO}_{2}$ increase), the hemoglobin releases higher oxygen quantities (Bohr's effect) (Carlson \& Bruss 2008). However, despite the blood gas changes observed in this study, the analysis of these parameters showed that the acute blood loss and subsequent transfusion with homologue fresh or stored blood were not sufficient to provoke metabolic or respiratory disruption in the animals, because all the blood gas parameters stayed inside the referral values for the species (Nunes et al. 2014).

In the oxidative stress analysis of the animals, there was no difference in the GPX activity among groups and times studied, differently from the SOD activity, in which was observed in the comparison among groups that after the transfusion until the T12, there was higher activity in the G15 and lower in the G35. Sousa (2012) when evaluating the oxidative stress in ovine transfused with fresh and stored blood did not observe difference between the groups for SOD and GPX. According to Nazifi et al. (2009) these enzymes are part of the antioxidant system of the goat and act protecting them from the action of free radicals, being the SOD the frontline of defense against these radicals. In this study, the SOD alteration in the G15 and G35 shows that there was a disorder in the antioxidant system in the goat of these groups, suggesting then that the greater SOD activity in the G15 was due to the larger quantity of free radicals in the 15-day bags, while the 35-day stored bags, because they had greater SOD consumption during storage, presented less free radicals, consequently causing lower antioxidant activity in the G35.

The MDA is one of the products of the lipid peroxidation and its concentration is widely used as cellular lesion indicator (Esterbauer \& Cheeseman 1990, Nazifi et al. 2009). In this study there was no difference among the groups for the MDA concentration, corroborating with Sousa (2012), which in a similar study with ovine, also did not observe difference in this parameter concentration among the animals that received stored and fresh blood. Thus, although the bags stored for 35 days presented higher MDA content, it is suggested that the cargo of reactive oxygen species contained in these bags was not enough to promote lipid peroxidation in the recipient animals.

\section{CONCLUSIONS}

The stored whole blood presented greater biochemical, blood gas, oxidative stress and lipid peroxidation changes when compared with fresh blood, but this did not impair its use as a therapeutic resource in goat.

The transfusion of whole fresh or stored blood in goat did not comprise the blood gas, lipid peroxidation, and hepatic and renal functions of the transfused animals; it has been shown to be effective in restoring total protein and albumin among other components, which can be used in animals with hypoproteinemia and hypoalbuminemia respectively.

The homologous transfusion of fresh or stored whole blood in goats as performed in this study has been shown to be safe for use in the clinical practice.

\section{REFERÊNCIAS}

Argôlo E.P. 2014. Respostas à perda sanguínea aguda em caprinos. Dissertação de Mestrado, Universidade Federal Rural do Semi-Árido, Mossoró, RN. 61p.

Barros I.O. 2011. Avaliação da conservação do sangue total de jumentos (Equus asinus) acondicionado em bolsas de sangue do tipo CPDA-1 e CPD/SAG-M. Dissertação de Mestrado, Universidade Federal Rural do Semi-Árido, Mossoró, RN. 79p.

Bertoletti B. 2011. Peroxidação lipídica e parâmetros bioquímicos do sangue total felino armazenado em bolsas plásticas contendo CPDA-1 e CPD/ SAG-M. Dissertação de Mestrado, Universidade Federal de Santa Maria, Santa Maria, RS. 42p.

Carlson G.P. \& Bruss M.L. 2008. Fluid, electrolyte and acid-base balance, p.529559. In: Kaneko J.J., Harvey J.W \& Bruss M.L. (Eds), Clinical Biochemistry of Domestic Animals. 6th ed. Academic Press, San Diego. <http://dx.doi. org/10.1016/B978-0-12-370491-7.00017-9>.

Costa Júnior J., Viana J.A., Ribeiro Filho J.D., Favarato E.S., Mata L.C. \& Argôlo Neto N. 2008. Parâmetros bioquímicos e hemogasométricos do sangue total canino armazenado em bolsas plásticas contendo. CPDA-1 e CPD/ SAG-M. Ciência Rural 38(2):378-383. <http://dx.doi.org/10.1590/S010384782008000200013>

Esterbauer H. \& Cheeseman K.H. 1990. Determination of aldehydic lipid peroxidation products: malonaldehyde and 4-hydroxynonenal. Methods Enzymol. 186:407-421. <http://dx.doi.org/10.1016/0076-6879(90)86134-H> <PMid:2233308>

Harvey J.W. 2008. The erythrocyte: physiology, metabolism, and biochemical disorders, p.173-240. In: Kaneko J.J., Harvey J.W. \& Bruss M.L. (Eds), Clinical 
Biochemistry of Domestic Animals. 6th ed. Academic Press, San Diego. <http://dx.doi.org/10.1016/B978-0-12-370491-7.00007-6>.

Hatherill J.R., Till G.O. \& Ward P.A. 1991. Mechanisms of oxidant-induced changes in erythrocytes. Agents Actions 32(3/4):351-358. <http://dx.doi. org/10.1007/BF01980898><PMid:1862753>

Hess J.R. 2009. Red cell storage: when is better not good enough? Blood Transfusion 7(3):172-173. <PMid:19657479>

Hess J.R. \& Greenwalt T.J. 2002. Storage of blood cells: new approaches. Transfus. Med. Rev. 16(4):283-295. <http://dx.doi.org/10.1053/tmrv.2002.35212> $<$ PMid:12415514>

Högman C.F. \& Meryman H.T. 1999. Storage parameters affecting red blood cell survival and function after transfusion. Transfus. Med. Revs 13(4):275-296. <http://dx.doi.org/10.1016/S0887-7963(99)80058-3><PMid:10553271>

Hunt E. \& Moore J.S. 1990. Use of blood and blood products. Vet. Clin. N. Am., Food Anim. Pract. 6(1):133-147. <http://dx.doi.org/10.1016/S07490720(15)30900-2><PMid:2178738>

Jackson P.G.G. \& Cockcroft P.D. 2002. Clinical Examination of Farm Animals. Blackwell Science, Oxford, p.304-305. <http://dx.doi.org/10.1002/9780470752425>.

Jóźwik M., Jóźwik M., Jóźwik M., Szczypka M., Gajewska J. \& Laskowska-Klita T. 1997. Antioxidant defence of red blood cells and plasma in stored human blood. Clin. Chim. Acta 267(2):129-142. <http://dx.doi.org/10.1016/ S0009-8981(97)00148-4><PMid:9469248>

Lacerda L. 2005. Transfusão sanguínea em veterinária: desafios a vencer. Anais II Simpósio de Patologia Clínica Veterinária da Região Sul do Brasil, Porto Alegre, RS, p.62-81. (Resumo)

Liebich H.-G., Forstenpointner G., Pérez W. \& König H.E. 2016. Introdução e anatomia geral, p.1-52. In: König H.E. \& Liebich H.-G. (Eds). Anatomia dos Animais Domésticos: texto e atlas colorido. $6^{\underline{a}}$ ed. Artmed, São Paulo.

Mudge M.C., MacDonald M.H., Owens S.D. \& Tablin F. 2004. Comparison of 4 blood storage methods in a protocol for equine pre-operative autologous donation. Vet. Surg. 33(5):475-486. <http://dx.doi.org/10.1111/j.1532950X.2004.04070.X><PMid:15362986>

Nazifi S., Saeb M., Ghafari N., Razeghian I., Razavi S.M., Vosoughi F., Dehghani F. \& Orangi H. 2009. Reference values of oxidative stress parameters in adult native iranian goats. Bulg. J. Vet. Med. 12(2):119-124.

Niinistö K., Raekallio M. \& Sankari S. 2008. Storage of equine red blood cells as a concentrate. Vet. J. 176(2):227-231. <http://dx.doi.org/10.1016/j. tvjl.2007.02.015><PMid:17449302>
Nunes T.L., Oliveira M.G.C., Paiva A.L.C., Bezerra T.C.G., Barrêto-Júnior R.A. \& Paula V.V. 2014. Valores hemogasométricos e eletrolíticos de caprinos (Capra Hircus) da raça Canindé criados no semiárido nordestino. Revta Bras. Med. Vet. 36(3):255-260.

Pugh D.G. 2004. Clínica de Ovinos e Caprinos. Roca, São Paulo, p.403-502.

Reichmann P. \& Dearo A.C.O. 2001. Transfusão de sangue e seus derivados em grandes animais. Semina, Ciênc. Agrárias 22(2):223-228.

Sousa R.S. 2012. Avaliação da transfusão sanguínea homóloga em ovinos. Dissertação de Mestrado, Universidade Federal Rural do Semi-Árido, Mossoró, RN. 168p.

Sousa R.S., Barros I.O., Tavares M.D., Sousa I.K.F., Oliveira G.B., Minervino A.H.H. \& Barrêto-Júnior R.A. 2012a. Lesões de armazenamento durante a conservação de sangue nas diferentes espécies: uma revisão. Acta Vet. Bras. 6(2):68-79.

Sousa R.S., Chaves D.F., Barrêto-Júnior R.A., Sousa I.K.F., Soares H.S., Barros I.O., Minervino A.H.H. \& Ortolani E.L. 2012b. Clinical, haematological and biochemical responses of sheep undergoing autologous blood transfusion. BMC Vet. Res. 8(1):61-67.<http://dx.doi.org/10.1186/1746-6148-8-61> <PMid:22607611>

Sousa R.S., Barrêto-Júnior R.A., Sousa I.K.F., Chaves D.F., Soares H.S., Barros I.O., Minervino A.H.H. \& Ortolani E.L. 2013. Evaluation of hematologic, blood gas, and select biochemical variables in ovine whole blood stored in CPDA-1 bags. Vet. Clin. Pathol. 42(1):27-30.<http://dx.doi.org/10.1111/ vcp.12014><PMid:23278354>

Tavares M.D. 2013. Avaliação hematológica, bioquímica e hemogasométrica de sangue caprino armazenado em bolsas CPDA-1 e CPD/SAG-M. Dissertação de Mestrado, Universidade Federal Rural do Semi-Árido, Mossoró, RN. 73p.

Tennant B.C. \& Center S.A. 2008. Hepatic function, p.379-412. In: Kaneko J.J., Harvey J.W \& Bruss M.L. (Eds), Clinical Biochemistry of Domestic Animals. 6th ed. Academic Press, San Diego. <http://dx.doi.org/10.1016/B978-012-370491-7.00013-1>.

Tomczak A.C.T.Q., Grilo K.T.M., Castro J.M., Machado A.M.B., Leonart M.S.S. \& Nascimento A.J. 2010. Estudo de métodos laboratoriais para o controle de qualidade de unidades transfusionais eritrocitárias no Centro de Hematologia e Hemoterapia do Paraná (Hemepar). Revta Bras. Hematol. Hemoter. 32(3):209-214. <http://dx.doi.org/10.1590/S1516-84842010005000076>

Wallas C.H. 1979. Sodium and potassium changes in blood bank stored human erythrocytes. Transfusion 19(2):210-215. <http://dx.doi. org/10.1046/j.1537-2995.1979.19279160297.x><PMid:155333> 